\title{
Genetic control of adventitious rooting on stem cuttings in two Pinus elliottii $\times$ P. caribaea hybrid families
}

\author{
Mervyn SHEPHERD ${ }^{\mathrm{a} *}$, Rohan MELLICK ${ }^{\mathrm{a}}$, Paul TOON $^{\mathrm{b}}$, Glenn DALE $^{\mathrm{c}}$, Mark DIETERS $^{\mathrm{b}, \mathrm{d}}$ \\ ${ }^{a}$ Cooperative Research Centre for Sustainable Production Forestry, and Centre for Plant Conservation Genetics, Southern Cross University, \\ Military Rd, Lismore, New South Wales 2480, Australia \\ ${ }^{\mathrm{b}}$ Cooperative Research Centre for Sustainable Production Forestry and Department of Primary Industries - Forestry, Fraser Road, Gympie, \\ Queensland 4570, Australia \\ c Tree Crop Technologies Pty Ltd, 112 Alexandra Street Bardon, Queensland, 4065, Australia \\ d Present Address: School of Land and Food Science, NRAVS, The University of Queensland, Brisbane, Queensland 4072, Australia
}

(Received 1 April 2004; accepted 2 March 2005)

\begin{abstract}
Genetic control of adventitious rooting was characterised in two unrelated Pinus elliottii $\times$ P. caribaea families, an outbred $\mathrm{F}_{1}(n=$ $287)$ and an inbred $F_{2}(n=357)$. Rooting percentage was assessed in three settings and root biomass was measured on a sub-set of clones $(n=$ $50)$ from each family in the third setting. On average, clones in the outbred $\mathrm{F}_{1}$ had a higher rooting percentage (mean $\left.\pm \mathrm{SE} ; 59 \pm 1.9 \%\right)$ and biomass (mean $\pm \mathrm{SD} ; 0.41 \pm 0.24 \mathrm{~g}$ ) than clones in the inbred $\mathrm{F}_{2}$ family (mean $\pm \mathrm{SE} ; 48 \pm 1.8 \%$ and mean $\pm \mathrm{SD} ; 0.19 \pm 0.13 \mathrm{~g}$ ). Genetic determination for rooting percentage was strong in both families, as indicated by high individual setting clonal repeatabilities (e.g. Setting 3; outbred $\mathrm{F}_{1} 0.62 \pm 0.03$ and inbred $\left.\mathrm{F}_{2} 0.68 \pm 0.02\left(\mathrm{H}^{2} \pm \mathrm{SE}\right)\right)$ and the moderate-to- high genetic correlations amongst the three settings. For root biomass, clonal repeatabilities for both families were lower (outbred $F_{1} 0.35 \pm 0.09$ and inbred $F_{2} 0.44 \pm 0.10\left(\mathrm{H}^{2} \pm \mathrm{SE}\right.$ )). Weak positive genetic correlations between rooting percentage and root biomass in both families suggested a concomitant gain in root biomass would be insignificant when selecting solely on the more easily assessable rooting percentage.
\end{abstract}

genetic variation / clonal repeatability / rooted cutting / rooting percentage / biomass

Résumé - Contrôle génétique de l'enracinement adventice de boutures de tiges dans deux familles hybrides de Pinus elliottii $\times P$. caribaea. On a étudié le contrôle génétique de l'enracinement adventice pour deux familles non apparentées de l'hybride Pinus elliotti $\times P$. caribaea, à savoir une famille $\mathrm{F}_{1}(n=287)$ issue de pollinisation croisée et une famille $\mathrm{F}_{2}(n=357)$ issue d'autofécondation. Le pourcentage de plants enracinés a été déterminé sur le matériel obtenu au cours de trois séries d'opérations de bouturage ; on a mesuré la biomasse racinaire sur un sous échantillon de clones $(n=50)$ issus de chaque famille de la troisième série. En moyenne, les clones de la famille $\mathrm{F}_{1}$ affichent un pourcentage d'enracinement (moyenne et intervalle de confiance $59 \pm 1,9 \%)$ et de biomasse $(0,41 \pm 0,24 \mathrm{~g}$ ) supérieurs à ceux de la famille autofécondée $\mathrm{F}_{2}(48 \pm 1,8 \%$ et $0,19 \pm 0,13 \mathrm{~g})$. Le déterminisme génétique du caractère pourcentage d'enracinement est élevé dans les deux familles comme l'indique le haut niveau de similitude de classement des clones dans chaque série (ainsi pour la série $3, F_{1} 0,62 \pm 0,03$ et $F_{2}$ $0,68 \pm 0,02)$; ainsi que le niveau moyen a élevé des corrélations génétiques entre les trois séries. Pour la biomasse racinaire, le classement des clones dans les 2 familles est plus variable $\left(\mathrm{F}_{1} 0,35 \pm 0,09\right.$ et $\left.\mathrm{F}_{2} 0,44 \pm 0,10\right)$. Les corrélations génétiques entre pourcentage d'enracinement et biomasse racinaire sont positives mais de faible valeur ; ceci inique qu'une sélection sur le seul critère pourcentage de plants enracinés, plus facile à mesurer, ne permet pas d'améliorer le critère biomasse racinaire de manière concomitante.

variabilité génétique / stabilité des aptitudes clonales / boutures racinées / pourcentage d'enracinement biomasse

\section{INTRODUCTION}

Clonal forestry encompasses systems for the efficient vegetative propagation and the delivery of improved and tested germplasm [18, 29]. While technological developments continue to increase the number of trees species for which clonal forestry is feasible, some long recognized problems still remain $[26,29,41]$. Many species of conifers (and other woody plants) produce vegetative propagules at operationally viable rates from young stock plants several years of age, but rates decline below acceptable limits as stock plant age increases [16, 24, 25]. An adverse relationship between stock age and field performance of cuttings is also common in many conifers. Maturation, therefore, is a key issue for clonal forestry in conifers where germplasm may require archiving during several years of clonal evaluation in field trials [13,24]. As propagation rates directly influence the economic viability of clonal forestry, a second challenge for clonal forestry arises in some species

\footnotetext{
* Corresponding author: mshepher@scu.edu.au
} 
because of the inherently poor amenability to vegetative propagation. Amongst the conifers, vegetative propagation of Monterey pine (Pinus radiata) by cuttings is regarded as relatively easy, whereas loblolly pine $(P$. taeda) and slash pine $(P$. elliottii) are more difficult to propagate from stem cuttings $[9,12,36,44]$.

Plantation forestry in subtropical and tropical Australia is primarily based on exotic pines. The hybrid between $P$. elliottii Engelm var. elliottii Little and Dorman and P. caribaea Morelet var. hondurensis Barrett and Golfari is the most suited taxa for the majority of the plantation estate on the coastal areas of central and south-east Queensland [19]. However, the $F_{1}$ hybrid is difficult and expensive to propagate by seed; therefore vegetative propagation is required for large scale deployment of this hybrid in plantations. In 2002, the annual planting requirement was supplied from hybrid stock consisting entirely of tested clones. The production of the hybrid pine is based on a rooted cutting system [43]. To achieve this, select controlled-cross hybrid families undergo field testing in clonal trials for up to six years (seven years from seed). During the field testing phase, each clone is stored in a clonal archive (as field hedges and in tissue culture). Utilization rates (i.e., the number of rooted cuttings suitable for field planting divided by the number of shoots initially set) for rooted cuttings for some container grown hybrid families can be high (86\%), but there are large differences in rooting rates amongst clones within families [17, 20]. Early hopes that maturation could be managed effectively through rejuvenation of mature trees by decapitation, and maintenance of juvenility by hedging and serial propagation [22], are now proving to be inadequate for many of the elite clones identified in clonal tests. Hedging can be effective in reducing or eliminating maturation in stool plants aged up to 7-8 years, the usual age for clonal selection, but its effect varies between clones [22], and only permits deployment of clones for a relatively short time (up to 4 years) once they have been selected in field tests. Consequently, the Queensland clonal forestry program with hybrid pine is currently limited in the range of genotypes that can be deployed. Two major limiting factors appear to be that (i) some genotypes never exhibit operationally viable rooting percentage and (ii) rooting percentage in most clones declines due to maturation effects as the stock plants' age increases.

We are interested in the genetic improvement of rooting characteristics in the $P$. elliottii $\times P$. caribaea hybrid. The potential benefits of eliminating clones that mature rapidly from deployment or before clonal testing was recognized early on, but research was focused on optimising propagation systems to overcome maturation and identifying morphological markers indicative of maturation [17, 20, 21, 23]. Significant phenotypic correlations between primary needle morphology and rooting ability were identified. Although shoots with favourable morphology are now selected from hedges, selective breeding has never been implemented, and there has been no experiment to ascertain the extent to which maturation is under genetic control. Operational experience with vegetative propagation of the $P$. elliottii $\times P$. caribaea hybrid has shown variation exists for maturation related effects as some clones and families retain juvenile rooting and vigour for long periods. One clone retained nearly $100 \%$ rooting success, when propagated by cuttings from hedge plants that had been serially propagated from a see- dling sown 17 years earlier (M. Dieters, unpublished data). There also remains little knowledge of the role of genetics in determining a clone's rooting ability before maturation occurs. It is known from studies of rooting in other conifers that the genetic determination of rooting can be high, e.g., loblolly pine (Pinus taeda), hybrid larch (Larix sp.) and western hemlock (Tsuga heterophylla) [1, 10, 35].

Here we report on the level of genetic control of rooting when cuttings are set using shoots collected from seedling ortets less than 3 years from seed (i.e., before maturation is believed to influence rooting). We report on the extent of variation and degree of genetic determination on the rate of root initiation and root quality on stem cuttings in two large hybrid families. The first family, an outbred $\mathrm{F}_{1}$ hybrid, was typical of controlledcross material used in the clonal program. The second family, an inbred $\mathrm{F}_{2}$, was an experimental population that is regarded as ideal for study genetic architecture including gene action by a quantitative trait loci (QTL) approach [34]. We found extensive variation in both families for rooting percentage and root biomass. We discuss possible genetic explanations for observed rooting properties.

\section{MATERIALS AND METHODS}

\subsection{Populations}

In 1998, a series of long term trials based on eight large (up to 408 individuals) full-sib $P$. elliottii $\times P$. caribaea hybrid families were established to investigate the genetics control in a range of commercially important traits using genetic mapping approaches $[6,7]$. Rooting success of cuttings has a major impact on the cost of plantation establishment, and relatively small improvements can save millions of dollars each year in plant production costs. The populations in this study comprised two unrelated interspecific hybrid families: one, an outbred $F_{1}$ family, and the other, a second generation hybrid family derived from the self-pollination of an $F_{1}$ individual. The outbred $F_{1}$ family was produced by controlled-pollination of a select $P$. elliottii var. elliottii (2ee1-102) maternal parent with pollen from a select $P$. caribaea var. hondurensis (1ch1-063) [7]. The inbred $\mathrm{F}_{2}$ family was produced by self-pollinating an $\mathrm{F}_{1}$ hybrid individual (eh43) that had been selected in the progeny of an $\mathrm{F}_{1}$ cross of 1 ee $1-015 \times 1$ ch6-029.

Seeds of each family were sown directly into $220 \mathrm{~mL}(50 \times 50 \times$ $125 \mathrm{~mm}$ ) "VIC" pots at in the DPI Forestry Nursery at Toolara, Queensland in February 1998. Germination rates were estimated to be $75 \%$ and $82 \%$ for the outbred $F_{1}$ and inbred $F_{2}$ respectively. In early March, once the majority of seed had germinated, the plants were transferred to the then Queensland Forestry Research Institute (QFRI) glasshouse facility at Gympie, Queensland and kept in full sun for several weeks before being transferred to a heated glasshouse for winter. The plants were topped during winter and again in early spring to promote multiple shooting. Seedlings were graded by size, and a few plants with poor vigour were discarded, giving final family sizes of 288 and 408 plants for the outbred $F_{1}$ and inbred $F_{2}$ families, respectively (note: family sizes which were a multiple of 12 were required by the design of the field test). Once the shoots had been harvested for the first setting, the seedling ortets were trimmed back after harvesting of shoots (see below) to promote the development of new shoots for subsequent settings. Following Setting 1 and prior to Setting 2 (see below), the seedling ortets were given slow-release (8-9 month) fertomozer o, February 1999. Ortets were topped to a height of approximately $150 \mathrm{~mm}$ in April and then planted out in the hedge production area at the Toolara nursery during May 1999. Ortets were maintained 
as hedges during the experiment by repeated topping to approximately $150 \mathrm{~mm}$ to minimize the development of maturation effects and to increase the number of shoots that could be set as potential cuttings.

\subsection{Vegetative propagation}

\subsubsection{Setting 1 (1998)}

The first setting (Setting 1) and second (Setting 2) setting were carried out with the primary objective of establishing a clonal field trial. To obtain sufficient material from each ortet, Setting 1 was conducted in two rounds. The first round on 28th September 1998 harvested up to seven shoots per clone, and the second round on 23rd November 1998 harvested up to nine shoots per clone. In the first round, shoots (approx. 30-90 $\mathrm{mm}$ in length) were set in $80 \mathrm{ml}(40 \times 40 \times 65 \mathrm{~mm})$ "NET" pots containing a commercial seed-raising mix, in a white polyhouse at the Gympie research facility [7]. A supplemental setting was conducted in early October 1998 to set further cuttings to ensure that as far as possible each clone was represented by a total of 7 cuttings in this setting. These supplemental cuttings were treated as part of the first round. All cuttings were misted regularly for 8-10 weeks after setting in the Gympie facility and then transferred to a shadehouse for two weeks prior to being moved into full sun. In late March and early April 1999, the cuttings were moved to the Beerburrum nursery and any shoots which had rooted were transplanted from NET to VIC pots containing a standard pine-bark-peat and sand mix used operationally at that time for raising $F_{1}$ hybrid cuttings. Cuttings were then maintained in full sun until they were ready for field planting in July.

In the second round of Setting 1, up to nine shoots (approx. 30$40 \mathrm{~mm}$ ) per clone were set into "micro-containers" (tray of $9 \times 18$ cells of $20 \mathrm{~mL}$ ) filled with the same potting mix as the first setting. Cuttings were kept in the white polyhouse under a similar misting regime for 8-10 weeks. Cuttings that had developed roots were transplanted into VIC pots containing the standard operational potting mix for cuttings. Plants were then transferred to the Beerburrum nursery where they were kept under shade for two weeks and given an application of $3-$ $4 \mathrm{~m}$ slow-release fertilizer, prior to being transferred into full sun. Unrooted cuttings were returned to the white polyhouse at Gympie. A second crop of cuttings was transplanted into VIC pots approximately 4-6 weeks later and transferred to the Beerburrum nursery. Nursery treatment was similar; however, the second crop of cuttings did not receive a supplemental application of slow-release fertilizer. A final supplemental setting was carried out in December to "top-up" a small number of clones that had insufficient ramets for the field trials. On 5th May 1999, all cuttings were fertilised with 3-4 month slowrelease fertilizer. Counts of rooted plants were conducted on 27th April 1999 (approx. 30 weeks post-setting) and on 5th May 1999 (approx. 24 weeks post-setting) for rounds one and two respectively.

\subsubsection{Setting 2 (1999)}

Material for Setting 2 was obtained from the seedling ortets after they had been planted as hedges at Toolara Nursery following Setting 1 . Again cuttings were set in two rounds to obtain sufficient material to establish a clonal field trial. The first round took place at the Beerburrum Nursery in the week of 26th October 1999, with up to 10 shoots (approx. 20-30 $\mathrm{mm}$ in length) harvested and set in VIC pots. A supplemental setting was carried out two weeks later to top-up the clones which had less than ten shoots in the initial setting. The second round of the setting took place on 21st Dec 1999, with up to ten shoots per clone set, followed by a supplemental setting on 10th January 2000. Cuttings were regularly misted in the shadehouse until root initiation had taken place. Once most clones had rooted, cuttings were transferred into full sunlight to grow and harden. Rooting assessment of the first round was carried out on 4th May 2000 (approx. 30 weeks post- setting), and assessment of the second round was carried out on 27th June 2000 (approx. 29 weeks post-setting).

\subsubsection{Setting 3 (2000)}

The third setting was undertaken specifically for the purpose of studying rooting initiation. Setting occurred at the Toolara nursery, commencing on the 11 th September 2000. A total of 12 cuttings per clone were set as four cuttings of each clone in three replicates. Cuttings were set into "microcontainers" in trays of $9 \times 18$ cells $(\sim 20 \mathrm{~mL}$ each). Clones were arranged sequentially within the nursery beds, within each replicate. Within a tray, the four cuttings from a clone were set in one column, one cell was left blank, and then the four cuttings of the next clone were set in the remaining four cells of that column. Hence, each tray contained 4 cuttings/clone $\times 36$ clones. Trays within each family, within each replicate were arranged randomly in the nursery. Nursery management followed a similar approach to that used in Setting 2 described above.

Additional material from each family was also set at the same time for a time-course experiment. Sufficient material was set to destructively sample one ramet from a random sample of 144 clones from each family at each of four time points. The objective of the time-course experiment was to allow timing of the assessment of rooting so that approximately $50 \%$ of clones had rooted in each family. Based on this destructive sampling, rooting percentage assessment was carried out on the 19th week following setting in January 2001 - approximately 10 weeks earlier than in Settings 1 and 2.

\subsection{Assessment of root quality - biomass measurements}

Following the assessment of rooting percentage in Setting 3 in January 2001 , one rooted cutting was randomly selected from each clone in each of the three replicates and harvested for biomass assessment. At harvest, potting medium was carefully washed from the roots and the plants were placed in labelled paper bags. Samples were then air dried prior to oven drying at $70{ }^{\circ} \mathrm{C}$ for two days. A random subset of 50 clones from each family was selected for biomass analysis. Cuttings were dissected into three segments: shoot, callus and root, and each segment was weighed individually. Two covariates were noted: measuring association of (1) algae and (2) extraneous matter (EM) with each cutting. Algae were largely associated with the above ground section of the cutting, whereas extraneous matter represented fungal hyphae (probably mycorrhiza) and adhering potting material which could not be separated from roots. Covariates were assessed using a four point visual rating from zero to three, with three indicating the highest level of associated algae or extraneous material.

\subsection{Data analysis}

Two types of analyses were conducted: the first compared performance in the two families, and the second estimated variance components within families to determine clonal repeatability and genetic correlations between settings. For the purposes of estimating variance components (see below), separate analyses were conducted for the two families rather than pooling the data together and treating family as an additional (fixed or random) effect in the model. The primary reason for this was the physical layout of the cuttings in the nursery - in all three Settings (1998-2000) cuttings from the two families were physically separated in the nursery. Due to the different inbreeding status of the families, it was expected that rooting ability of clones within these two families would be markedly different and that different nursery management regimes would be required. As these populations were set up for molecular genetic studies, the primary interest in these experiments was comparison of clonal performance within family, and so a design was adopted to maximize the precision of within family 
performance. As a consequence of this physical separation of the two families in the nursery, differences in family performance may be partially attributed to differences in the nursery environment and management that was experienced by the clones from setting to the time of assessment. Further, as the experiment only included two families, estimation of the variance between families would not be meaningful, and differences in family size and inbreeding status $(F=0$ vs. $F=0.5)$ led to the expectation that the families would have different levels of observed (phenotypic) variance.

\subsubsection{Comparison between inbred and outcross families}

Having recognized the limitations of these populations and the experimental design, analyses were undertaken to make approximate comparisons between the two families in terms of their rooting performance across the three settings, for Setting 3 alone, and for root biomass in Setting 3. Setting 3 was analysed separately because this setting was specifically set-up to investigate variation in rooting performance. In these analyses, family and replicate (or setting) were treated as fixed effects, and clone within family as random. Analyses were conducted in SPSS for windows vers. 10 (SPSS Inc. Chicago, IL) using the UNIVARIATE module and Type III sums of squares method of the general linear models (GLM module, using the following statistical model:

$$
y_{i j k}=\mu+R_{i}+F_{j}+C_{k(j)}+E_{i j k},
$$

where $R_{i}$ is the fixed effect of replicate (i.e. round or block within Settings 1,2 or 3$), F_{j}$ is the fixed effect of the $j t h$ family, $C_{k(j)}$ is the random effect of the $k t h$ clone within the $j t h$ family, and $E_{i j k}$ is the residual error.

Analysis of variance of root biomass was carried out using the same model described above for rooting percentage but included covariates for the presence of algae and extraneous matter. Where covariates were found to be significant, an adjusted root biomass variable was used for correlation analysis generated from non-standardised residuals by the UNIVARIATE procedure in the GLM module of SPSS. Pearson's correlation coefficients were tested at the 0.05 level with a two-tailed significance test to determine whether clonal means for root biomass and rooting percentage were correlated in Setting 3.

\subsubsection{Estimation of variance components within family}

For the purposes of estimating the genetic control of rooting within each family, a joint analysis was conducted in ASREML [14] using the average rooting of each clone in each 'replicate' as the input data. Root initiation was observed as a binomial trait (i.e., $0=$ no roots, and 1 = roots), therefore the replicate mean data analysed was expected to be approximately normally distributed under the central limit theorem ([32] p. 319). In Setting 1 (1998) and in Setting 2 (1999) the two rounds of each setting essentially form two replicates separated temporally by approximately 2 months. Effects due to differences in the propagation methods used in rounds 1 and 2 of Setting 1 will be confounded with replicate effects. For the purpose of this analysis, therefore, we treated the data as if we had two replicates in 1998 and 1999 and three replicates in 2000. The combined analysis (i.e., across the three settings) was developed in a step-wise fashion starting with the analysis of each setting separately, and then using the estimated variance components as priors for the next step.

Mean rooting data for each clone, in each setting, were analysed separately for each of the two families using the following model to estimate the residual variance:

$$
y_{i j}=\mu+R_{i}+C_{j}+E_{i j} \text {, }
$$

where, $y_{i j}$ is the clonal mean rooting percentage for the $j$ th clone in the $i t h$ replicate, $R_{i}$ is the fixed effect of the ith replicate, $\mu$ is the overall mean, $C_{j}$ is the random effect of the $j t h$ clone and $E_{i j}$ the residual error.

Data were then combined across settings, using the between clone and residual variances as estimated from the analysis of each setting as the initial priors and a separate residual variance fitted for each Setting. The final model used for the combined analysis was as follows:

$$
y_{i j k}=\mu+S_{i}+R_{i(j)}+C S_{i k}+E_{i j k},
$$

where effects in the model are as previously described except $y_{i j k}$ is the clonal mean rooting percentage of the $k t h$ clone in the ith Setting and $j$ th replicate (replicates were assigned unique numbers across all three Settings), effects of both setting $\left(S_{i}\right)$ and replicate within setting $\left(R_{i(j)}\right)$ were treated as fixed, and $C S_{i j}$ is the random interaction between the $k t h$ clone and the $i t h$ setting. Separate residual variances were fitted for each setting. An unstructured variance/covariance matrix was fitted for the clone $\times$ setting interaction to provide unconstrained estimates of the variance between clones in each setting and for the covariance between clones in all pair-wise combinations of the three settings.

Analysis of variance was conducted on root biomass using the data from the single setting using the model described above and with a replicate corresponding to a set of 50 ramets (representing 50 clones) from each of the 3 replicates in the nursery. Preliminary analysis of the data in SPSS indicated that the use of extraneous matter as a covariate on root dry-weight provided a significantly improved fit to the observed data (see results). Consequently, we used extraneous matter as a covariate for the purposes of estimating the variance components for root dry weight.

\subsubsection{Clonal repeatability estimates}

The post-procession options in ASREML were then used to estimate clonal repeatability (i.e., broad-sense heritability) for rooting percentage in each setting, using the variance components estimated from (a) the separate analyses of each setting, and (b) the final-step of the across-setting analysis, by dividing the genetic variance by the sum of all other variances estimated for that setting. Genetic correlations between each setting (for each of the two families) were estimated by dividing the covariance between clones in two different settings by the product of the standard deviations between clones that were estimated at the two sites. ASREML uses a Taylor series approximation to estimate the standard errors associated with the estimated clonal repeatabilities and genetic correlations (e.g. [8]).

\section{RESULTS}

All clones in the outbred $\mathrm{F}_{1}$ family rooted in at least one setting, but two clones (1022 and 1162) in the inbred $F_{2}$ family never produced a rooted cutting in any of the three Settings. Analysis of variance for rooting percentage over the three settings indicated all effects (setting, family and clone within family) were highly significant $(p<0.001)$ (ANOVA not shown). The average rooting percentage over the three settings for the outbred $\mathrm{F}_{1}$ family (mean $\pm \mathrm{SE} ; 73 \% \pm 0.9 \%$ ) was approximately $10 \%$ higher than the inbred $\mathrm{F}_{2}$ (mean $\pm \mathrm{SE} ; 65 \% \pm$ $0.9 \%$ ) (Tab. I). The highest average rooting percentage for both families occurred in Setting 2 whereas the lowest averages were in Setting 3.

Based on data from Setting 3, rooting percentage for each family was approximately normally distributed (Tab. II). Despite a non-significant departure from normality, there was a tendency 
Table I. Family mean rooting percentages ( \pm standard error) for two hybrid families, with the number of clones presented by each family mean indicated in parentheses.

\begin{tabular}{lcccc}
\hline & Setting 1 (1998) & Setting 2 (1999) & Setting 3 (2000) & Marginal means \\
\hline Outbred $F_{1}$ & $74 \pm 1.4$ & $87 \pm 1.0$ & $59 \pm 1.9$ & $73 \pm 0.9$ \\
Inbred $F_{2}$ & $(286)$ & $(287)$ & $(260)$ & $65 \pm 0.9$ \\
& $67 \pm 1.6$ & $78 \pm 1.4$ & $(324)$ & 68 \\
Marginal means & $(344)$ & $82 \pm 0.9$ & $53 \pm 1.2$ & $68 \pm 0.7$ \\
\hline
\end{tabular}

Table II. Frequency distribution parameters for rooting percentage and root biomass in Setting 3.

\begin{tabular}{llccccccc}
\hline Family & \multicolumn{1}{c}{ Trait } & $\mathrm{N}$ & Mean & $\mathrm{CV}(\%)$ & Min. & Max. & Skew & Norm. ${ }^{1}$ \\
\hline Outbred $\mathrm{F}_{1}$ & Rooting $\%$ & 260 & 59 & 52 & 0 & 100 & -0.29 & $\mathrm{Y}$ \\
& Biomass $(\mathrm{g})$ & 50 & 0.41 & 59 & 0 & 1.29 & 0.93 & $\mathrm{~N}$ \\
\multirow{2}{*}{ Inbred $\mathrm{F}_{2}$} & Rooting $\%$ & 324 & 48 & 82 & 0 & 100 & 0.72 & $\mathrm{Y}$ \\
& Biomass $(\mathrm{g})$ & 43 & 0.19 & 68 & 0 & 0.57 & 0.36 & $\mathrm{Y}$ \\
\hline
\end{tabular}

${ }^{1}$ Normality test (Kolmogorov-Smirnov with Lilliefor's Sign. Corr.) $\mathrm{Y}=p$-value $<0.05 ; \mathrm{N}=p$-value $>=0.05$.

Table III. Clonal repeatability of rooting percentage and root biomass ( \pm standard error) estimated from separate analyses of each setting and family.

\begin{tabular}{lcc}
\hline Trait/Setting (year) & Outbred $F_{1}$ Family & Inbred $F_{2}$ Family \\
\hline \multicolumn{1}{c}{ Rooting percentage $(\%)$} & & $0.19 \pm 0.049$ \\
Setting 1 (1998) & $0.28 \pm 0.055$ & $0.68 \pm 0.028$ \\
Setting 2 (1999) & $0.55 \pm 0.041$ & $0.68 \pm 0.023$ \\
Setting 3 (2000) & $0.62 \pm 0.029$ & $0.44 \pm 0.095$ \\
$\quad$ Root biomass (g) & $0.35 \pm 0.093$ & \\
Setting 3 (2000) & & \\
\hline
\end{tabular}

toward multi-modality in both families: bi-modality in the outbred $\mathrm{F}_{1}$ and tri-modality in the inbred $\mathrm{F}_{2}$ family (Figs. 1a and 1b). Analysis of variance of rooting percentage in the third setting indicated the family, and clone within family effects were highly significant $(p<0.001)$, whereas the replicate effect was significant $(p=0.051)$ (ANOVA not shown).

The distribution of root biomass (i.e., root dry-weight) in the inbred $\mathrm{F}_{2}$ family was approximately normal, but the distribution was non-normal in the outbred $F_{1}$ family (Tab. II). Both families had a small class of clones with extremely high root biomass: however, the positive skew was more pronounced in the outbred $F_{1}$ (Figs. $2 a$ and $2 b$ ). Analysis of variance for root biomass indicated family, clone within family, and the extraneous matter covariate were all highly significant $(p<0.001)$, but the replicate and the algae covariate were not significant $(p>0.25)$ (ANOVA not shown). A higher value of root biomass was associated with a higher extraneous matter covariate score, suggesting that it was more difficult to clean extraneous matter (e.g. fungal hyphae and potting media) from cuttings with more vigorous root systems. Because of the significance of this covariate, further analysis of root biomass was carried out using adjusted values by regressing out the extraneous matter covariate. Root biomass was significantly higher on average for a clone from the outbred $F_{1}$ compared with the inbred $F_{2}$ family (Tab. II). Clonal mean root biomass was not correlated with clonal mean rooting percentage in either family (Outbred $\mathrm{F}_{1}-n=48, r=0.17 \mathrm{~ns}$; Inbred $\mathrm{F}_{2}-n=40, r=0.234 \mathrm{~ns}$ ).

The clonal repeatability estimates for rooting percentage obtained from the separate analysis of each family in the three settings (Tab. III) were almost identical to those from the combined analysis (Tab. IV) and indicated a lower heritability $(0.28$ and 0.19 for the outbred $F_{1}$ and inbred $F_{2}$ families respectively) in Setting 1 compared to estimates of 0.55 to 0.68 in the subsequent two settings (Tab. III). This suggests environmental variation contributed more to overall phenotypic variation in Setting 1 compared to the later settings. However, the total phenotypic variance observed was generally less in Setting 1 (675.4 and 660.6 in the outbred $F_{1}$ and inbred $F_{2}$ families respectively) than in the following two settings; Setting 2 (421.5 and 784.3) and Setting 3 (1287 and 1345). The estimated clonal repeatability of root biomass from Setting 3 ( 0.35 and 0.44 for the outbred $F_{1}$ and inbred $F_{2}$ families respectively) were considerably lower, by contrast, than those for rooting percentage (Tab. III). The standard errors associated with the clonal repeatability of root biomass were approximately 3 times those for rooting percentage, reflecting the smaller number of clones sampled for rooting biomass. 
Table IV. Clonal repeatability of rooting percentage (in bold on diagonals) and genetic correlation (below diagonal) and their standard errors estimated from a combined analysis across the three settings. The model used fitted separate between clone and residual variance for each setting, and data from the outbred $F_{1}$ and inbred $F_{2}$ families were analysed separately.

\begin{tabular}{|c|c|c|c|}
\hline Setting (Year) & Setting 1 (1998) & Setting 2 (1999) & Setting 3 (2000) \\
\hline \multicolumn{4}{|c|}{ Outbred $F_{1}$ Family } \\
\hline Setting 1 (1998) & $0.28 \pm 0.055$ & - & - \\
\hline Setting 2 (1999) & $0.86 \pm 0.091$ & $0.55 \pm 0.041$ & - \\
\hline Setting 3 (2000) & $0.70 \pm 0.086$ & $0.75 \pm 0.048$ & $0.63 \pm 0.029$ \\
\hline \multicolumn{4}{|c|}{$\mathrm{F}_{2}$ Inbred Family } \\
\hline Setting 1 (1998) & $0.20 \pm 0.048$ & - & - \\
\hline Setting 2 (1999) & $0.70 \pm 0.105$ & $0.68 \pm 0.028$ & - \\
\hline Setting 3 (2000) & $0.61 \pm 0.103$ & $0.76 \pm 0.034$ & $0.68 \pm 0.023$ \\
\hline
\end{tabular}

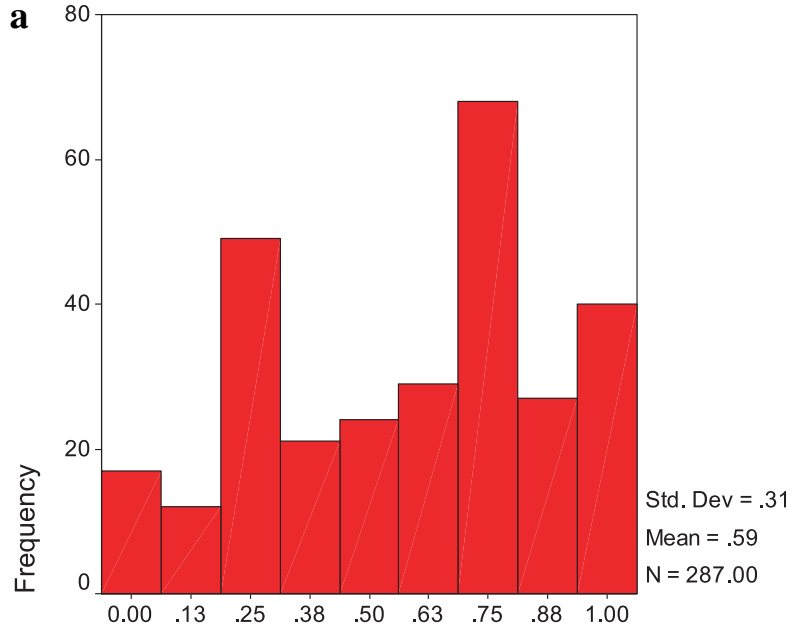

Proportion of ramets rooted

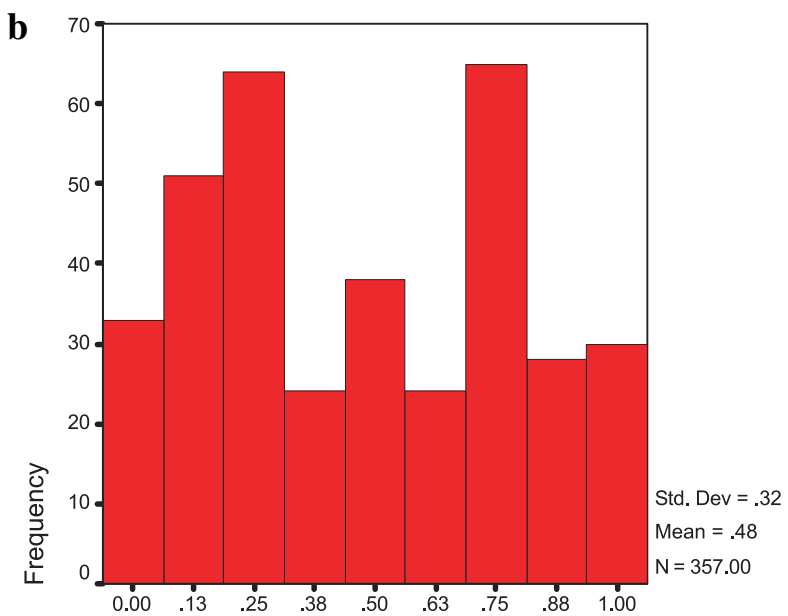

Proportion of ramets rooted

Figure 1. Frequency distributions for the rooting percentage for two hybrid pine families (a) outbred $\mathrm{F}_{1}$ family and (b) inbred $\mathrm{F}_{2}$ family.

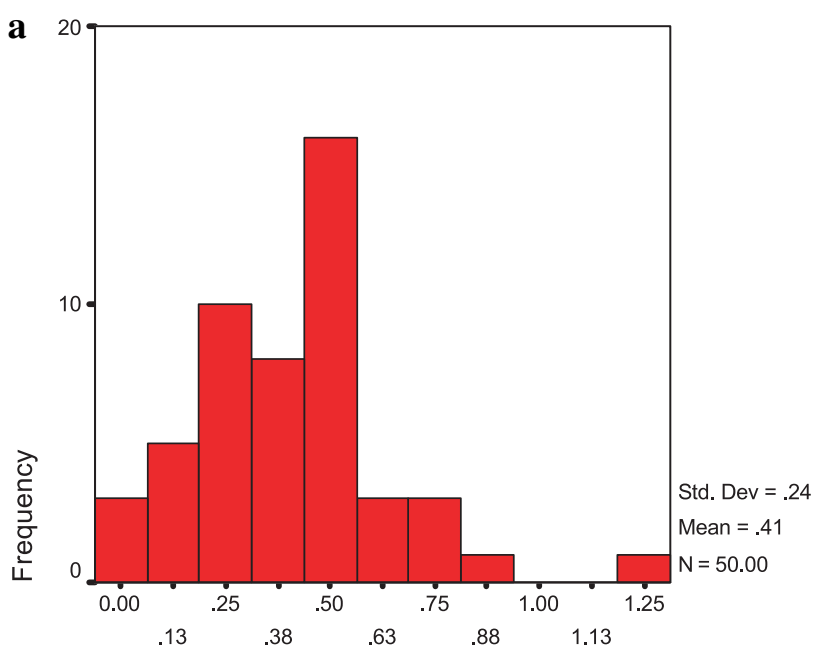

Root Biomass $(g)$

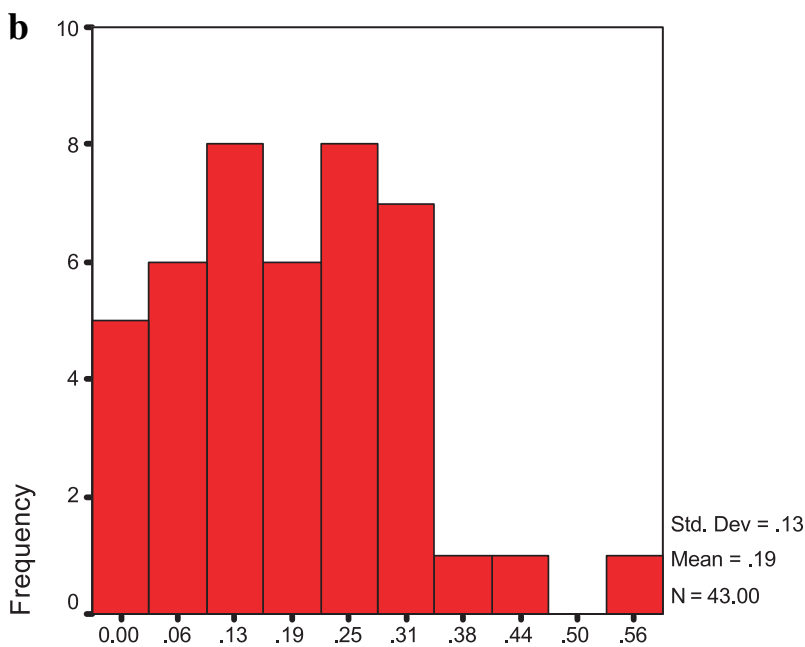

Root Biomass (g)

Figure 2. Frequency distributions for adjusted root biomass in two hybrid pine families (a) outbred $\mathrm{F}_{1}$ family and (b) inbred $\mathrm{F}_{2}$ family. 
Comparing the two families, clonal repeatability estimates for the outbred $F_{1}$ tended to be lower than those estimated in the inbred $\mathrm{F}_{2}$ (Tabs. III and IV). This suggests a greater variance between clones in the inbred family, since clones in both families were growing side-by-side in very similar nursery situations, and there is no reason to believe that either family should have been subject to more/less variable environmental conditions following setting.

From the combined analysis (Tab. IV), the genetic correlations between Settings were all positive and moderate to high (>0.6; Tab. IV), with the settings from sequential years (i.e., Settings 1 and 2, or Settings 2 and 3) tending to be more strongly correlated than Settings 1 and 3. Correlations amongst settings for the outbred $F_{1}$ also tended to be higher than those for the inbred $\mathrm{F}_{2}$ family. Lower genetic correlations in the inbred $\mathrm{F}_{2}$ family compared to the outbred $\mathrm{F}_{1}$ suggest the progressive development of adverse impacts on rooting performance due to maturation or inbreeding depression, might be greater in this family. However, as the differences in the genetic correlations are unlikely to be significant given the size of the associated standard errors, not too much emphasis can be placed on this limited data.

\section{DISCUSSION}

\subsection{Implications for within-family selection for rooting percentage and root biomass in the $P$. elliottii $\times$ $P$. caribaea hybrid.}

In this study, we have shown that $P$. elliottii $\times P$. caribaea hybrid families are highly variable for rooting percentage and root biomass and have moderate to strong clonal repeatabilities. The lower clonal repeatabilities observed in Setting 1 compared with the following settings were probably due to a combination of factors, including (1) an inappropriate medium used for setting of cuttings (which meant that the cuttings had to be transplanted into larger pots with a different potting mix), (2) large spatial variation in the distribution of water in the Gympie whitehouse (subsequently corrected in Setting 2), and (3) a lack of experience raising micro-cuttings. Until this time, larger $(100 \mathrm{~mm})$ shoots were used for propagation of hybrid pine cuttings. This suggests that the 'true' within-family repeatability of root initiation in hybrid pine cuttings was likely to be strong (approx. 0.6, Tabs. III and IV) and that this trait is under strong genetic control. Estimates of within-family clonal repeatability for root biomass were not as reliable (larger standard errors, and based on only 50 clones per family), but also indicate a relatively high level of genetic control (approximately 40\%) of root biomass production on cuttings that initiated roots.

Although the capacity to initiate roots on stem cuttings was almost universal (all outbred $F_{1}$ and all but 2 inbred $F_{2}$ clones formed rooted cuttings in at least one setting), the percentage of ramets cuttings rooted per clone was highly variable within each of the two $P$. elliottii $\times P$. caribaea families. The variance due to differences amongst clones, within a family, was large (60-70\%) for single settings and moderate (30-40\%) for multisetting estimates. These clonal repeatabilities indicate a high level of genetic determination for rooting ability of clones 1-3 years from seed. Therefore, pre-selection of clones within families with rooting percentages close to $100 \%$ is expected to effectively increase average rooting percentages of the clones in field tests. For example, if clones with $100 \%$ rooting are selected (i.e. selection intensity $13 \%$ ) and $\mathrm{H}^{2}=0.55$, the calculated expected gains in the outbred $F_{1}$ family in the second setting is $7.15 \%$.

Root biomass was also highly variable within each family $(\mathrm{CV} ; 59-68 \%)$ and appeared to be independent of root initiation. These results indicate that selection to improve root quality may not be as important as selection for root initiation. Whether or not a cutting develops roots has a major impact on nursery costs, clones with both high and low rates of root initiation are able to develop vigorous roots systems on those cuttings which do initiate roots, and the clonal repeatability of biomass production appears to be more affected by environment than rooting percentage. Further, there appears to be greater scope to better manage nursery conditions to promote vigorous root development on cuttings once they have initiated roots (i.e., about $60 \%$ of the observer variation was not genetic). Similar results were also found in a study of hybrid larch where the rooting percentage of a clone was not correlated with its ability to form "well-rooted" cuttings and broad sense heritabilities for the "well-rooted" variable were lower than those for rooting percentages [35]. A lack of correlation between root quality and root initiation has been attributed to a difference in the genes controlling these processes [35].

\subsection{Genetic factors contributing to family and within family differences in the $P$. elliottii $\times P$. caribaea hybrid}

Genetic control of rooting percentages has been variously attributed to provenance ((Platanus occidentalis [38]), family (P. taeda [11]), and within-family effects (P. taeda and hybrid larch $[11,35]$. Extreme differences amongst clones within families, are common in conifers and other forest tree species (e.g., [1, 42]). In hybrids, the variation attributable to clones within families can be large compared to family variance. For example, in hybrid larch, Radosta et al. (1994) found clonal variation within a family was six-fold greater than variance due to family. Genetic differences amongst clones within a family should largely be a consequence of segregation due to heterozygosity in one or both parents or grandparents. In our case, where there is evidence of hybrid incompatibility, variation in the $F_{1}$ hybrid may have been further increased because of the extremely poor vigour (and low rooting rates) in some $F_{1}$ individuals. Variation in the inbred $F_{2}$ family may also have been increased due to the effects of inbreeding (see below). Additionally, in our study, "C" effects were not partitioned out. Hence, they had the potential to inflate clonal variance and heritability $[30,45]$ (see below). Family variance was not estimated in our study because it was not thought to be meaningful based on only two families with different levels of inbreeding. However, experience with the propagation of hybrid families for clonal testing indicates, that almost all families can be successfully propagated by cuttings from juvenile material (i.e., from seedling hedges less than 4 years of age). Family variance is expected to be small compared to clonal variance within families in hybrid pines. 
The interspecific nature of both crosses in our study was also likely to have contributed to their high variability. The variance in an interspecific inbred $\mathrm{F}_{2}$ should be particularly high if the grandparents are derived from populations that differ as a result of divergent selection. Natural selection for adaptive traits may lead to contrasting and reduced allele diversity in the parental populations (i.e., grandparental species populations in this case) and consequently large segregating effects may occur in $\mathrm{F}_{2}$ and backcross hybrids $[3,40]$. The inbred $\mathrm{F}_{2}$ we have used was analogous to the inbred line crosses between divergent parent used by crop breeders to create segregating $\mathrm{F}_{2}$ populations [3]. Pinus elliottii contrasts with $P$. caribaea in primary and adventitious rooting characteristics, and since neither species naturally propagates vegetatively, it can be reasonably assumed that at least a subset of the genes controlling root initiation and growth on seedlings are the same as the genes controlling these traits in cuttings. P. elliottii exhibits greater wind firmness and an ability to develop adventitious roots in response to flooding than either the hybrid or $P$. caribaea $[2,28]$. These differences are probably a consequence of divergent selection in their natural environments, upland ridge sites in Belize, South America versus water logged sandy soils in Georgia and north Florida (USA) for $P$. caribaea and $P$. elliottii, respectively $[15,33]$. Larger segregating effects in the inbred $\mathrm{F}_{2}$ compared to the outbred $F_{1}$ may explain the slightly larger clonal repeatabilities observed in the inbred $\mathrm{F}_{2}$ family; however, this could also simply reflect differences in the two families selected for this study. A larger sample of $F_{1}$ and $F_{2}$ families would be required to confirm this observed trend.

Differences in the genetic structures of the two hybrid families were consistent with observed differences in their population parameters: family means, variances and frequency distributions. The two families differed in their degree of inbreeding; hence, the importance of additive, non-additive and interaction effects will vary in each family. Conifers are outcrossing and tend to have high genetic loads. As a consequence, inbred individuals often exhibit reduced vigour [46]. Inbreeding in the $\mathrm{F}_{2}$ probably accounted for the lower rooting performance in this family, but other factors including the difference in parentage and the potential for transgressive segregation in the $F_{2}$ and heterosis in the $\mathrm{F}_{1}$ could also account for the differences in performance.

\subsection{Multi-modal frequency distributions suggest major gene effects for rooting}

Multi-modal frequency distributions can be an indication of major gene effects in segregating families but distributions may be masked by variance due to environmental and epistatic effects [39]. The tri-modality observed in the inbred $\mathrm{F}_{2}$ was consistent with the frequency distribution expected for a trait controlled by a single gene trait (with a lack of dominance) that may be evident in an $\mathrm{F}_{2}$ between divergent inbred lines. The correspondence of rooting percentage phenotypes with molecular markers has subsequently been established by quantitative trait analysis (QTL) in these families [37]. Three QTLs were identified which explained approximately $40 \%$ of phenotypic variation for rooting percentage in the inbred $F_{2}$. Gene action at QTLs in this family was largely additive, suggesting dominance was not important in the inbred $\mathrm{F}_{2}$ for rooting per- centage. Clones homozygous for marker phenotypes associated with the unfavourable QTL alleles tended to fall in the extremely low rooting phenotype class.

Bimodality in the distribution of outbred $F_{1}$ may also be explained by genetic effects. Bimodality was consistent with at least one parental species possessing contrasting alleles at a single major gene, and therefore analogous to a backcross. Correspondence between genotype and phenotype in this family was also established by QTL analysis [37].

\subsection{Non-genetic and interaction causes of variation and their impact on the accuracy of variance and heritability estimates}

Maturation can be major problem reducing the rate of rooting success of cuttings in many conifers $[16,24]$ and indeed most woody plants [25]. However, we believe maturation was not a significant factor influencing rooting characteristics in our experiment because of the young stock plant age and stock plant management regime. In our trial, propagules were derived from stock plants less than two years and seven months from seed. Stock plants (ortets) were maintained at a height of $10-15 \mathrm{~cm}$ by hedging. This treatment has been shown to be effective in maintaining juvenile rooting responses in operational hedges of $P$. elliottii $\times P$. caribaea hybrids till at least age 3 years [22]. A further study of rooting has now been undertaken to test for maturation related effects on rooting. In particular, we seek to test whether rooting percentage in stock plants 1-2 years from seed correlates with rooting percentages approximately 6 years from seed, an age when stock plant maturation is believed to impact rooting rates.

The major non-genetic factors contributing to variation in this study were thought to be environmental and nursery management. Variation due to environmental effects is typically the largest source of variation in studies of rooting on stem cuttings (e.g., 28 and $41 \%$ for Loblolly pine $[1,11])$. The magnitude of differences between settings in our study was evident in the significance of the replicate effect in the multi-setting analysis of rooting percentage. The significance of the multi-setting replicate effect was likely to be largely the result of intentional modifications to the nursery and experimental procedure, as nursery practices were changed between settings and settings were managed for different objectives. Settings 1 and 2 were managed to maximize the number of rooted cuttings suitable for outplanting in field tests, whereas Setting 3 was managed specifically to maximize within family variation for rooting.

A major difference thought to cause lower rooting percentages in Setting 3 was the earlier assessment time. Setting 3 was assessed for rooting at 19 weeks post-setting as opposed to around 30 weeks in the first two settings. A time course experiment indicated that rooting percentages continued to rise up until at least 19 weeks post-setting (data not shown). Therefore, the earlier assessment time rather than stock plant maturation effects was thought to account for the overall lower rooting percentages in Setting 3 compared with earlier settings. A further factor believed important in inter-setting variability in our study was pot type. The use of inappropriate potting mixture in NET pots in Setting 1 caused problems with water logging that was thought to reduce rooting in this first year. Other environmental factors, 
including the climate and the health of cuttings, were also likely to have contributed to inter-setting differences.

A further important environmental source of variation in clonal trials can be due to physiological or morphological differences in the stock plants, so called "C" effects [27]. "C" effects are important because they lead to an overestimation of genetic variance components and biased heritability estimates [5, 30, 45]. "C" effects, for example, include differences in stock plants' maturation rates or their response to a fertilizer or a watering regime and are a characteristics of the particular environment in which the stock plant is grown [31]. In our study, "C" effects were confounded with clone differences and therefore would inflate estimates of clonal repeatability estimates. The significance of "C" effects in our study are unknown, but studies in other trees has shown they can be large for rooting percentages [35] and significant, but small, for rooting quality characteristics [45].

In comparison to "C" effects, "c" effects relate to variation within an individual and tend to inflate differences between propagules, hence lower estimates of heritability [4, 30]. "c" effects are often called position effects and may be due to physiological differences between progagules taken from the same stock plant. For example, "position" effects, may occur depending on whether a ramet is obtained from the upper or lower section of a crown or upper or lower position on a single branch. Both these types of position effects have been found to be significant in western hemlock (Tsuga heterophylla) [10] whereas the latter was significant in cottonwood (P. deltoides) [47]. In our study, there was the possibility of "c" effects in Setting 3 due to differences in the morphology or physiological age of the ramets taken from the centre compared to those from the periphery of the stock plant (ortet). However, in an effort to counter these potential differences, all shoots were selected to have similar morphology. In the first 2 settings, all shoots from a stock plant were morphologically similar as stock plants were not sufficiently developed to exhibit apparent differences. We have not estimated "c" effects but they would contribute to within plot variance and be partitioned into error and therefore lower our estimates of heritability. Genotype by environment interaction can also be a significant source of variation in multisetting experiments [11]. In his study of loblolly pine, Foster (1990), found that although variances attributable to parent $x$ trial interactions were not large $(2-4 \%)$ they were significant and similar in magnitude to the family effect.

\section{CONCLUSIONS}

Root initiation in hybrid pine clones was almost universal, but variation within a family for both rooting percentage and root biomass was extensive. The stronger genetic control and the greater economic imperative to increase rooting percentage suggest it will have a higher priority for genetic improvement than root biomass. The observed clonal repeatabilities for rooting percentage suggest that within-family selection will be effective, and therefore clones with higher rooting percentages will be selected when future tests are initiated to identify clones for commercial deployment. For root biomass, because environmental factors have a greater role in its determination, the most promising approach to achieve improved nursery outco- mes appears to be by manipulating nursery time and conditions. Unfortunately, because the two traits have a low genetic correlation, there appears to be little scope for concomitant gains in both traits by selecting on the more easily assessable rooting percentage. Differences in the genetic and phenotypic parameters between the families were consistent with that expected from their different genetic structures. Lower rooting percentages and biomass but higher within-family variances in the inbred $\mathrm{F}_{2}$ compared to the outbred $\mathrm{F}_{1}$ family, was consistent with the larger segregating effects and inbreeding depression expected in this family. Multi-modal frequency distributions in both families were suggestive of relatively simple modes of inheritance for rooting percentage in hybrid pines.

Acknowledgements: The authors thank M. Baxter and DPIF staff for assistance in the nursery, D.G. Nikles for help with literature research and M. Rolfe and L. Brooks for support with statistical analysis.

\section{REFERENCES}

[1] Anderson H.V., Frampton J., Mott R.L., Spaine P.C., Shoot production and rooting ability of cuttings from juvenile greenhouse loblolly pine hedges, Transactions of the Illinois State Academy of Science 92 (1999) 1-14.

[2] Anonymous, Queensland Department of Forestry report of research activities, Division of Technical Services, Queensland Department of Forestry, (1977) 52.

[3] Bradshaw H.D.J., Stettler R.F., Molecular genetics of growth and development in Populus. IV. Mapping QTLs with large effects on growth, form, and phenology traits in a forest tree, Genetics 139 (1995) 963-973.

[4] Burdon R.D., Bannister M.H., Low C.B., Genetic survey of Pinus radiata. 4: Variance structures and heritabilities in juvenile clones, N. Z. J. For. Sci. 22 (1992) 187-210.

[5] Burdon R.D., Shelbourne C.J.A., The use of vegetative propagules for obtaining genetic information, N. Z. J. For. Sci. 4 (1974) 418425 .

[6] Dieters M., Working Plan - Field phase cloned progeny trials of Pinus elliottii $\times P$. caribaea hybrids for genetic mapping experiments, Technical Report 24, CRC for Sustainable Production Forestry, 1999, pp. 1-9.

[7] Dieters M., Working Plan - Nursery phase cloned progeny trials of Pinus elliottii $\times P$. caribaea hybrids for genetic mapping experiments, Technical Report 23, CRC for Sustainable Production Forestry, 1999, pp. 1-6.

[8] Dieters M.J., White T.L., Littell R.C., Hodge G.R., Application of approximate variances of variance components and their ratios in genetic tests, Theor. Appl. Genet. 91 (1995) 15-24.

[9] Fielding J.M., Methods of raising Monterey pine from cuttings in the open nursery, Forestry and Timber Bureau Bulletin 32, Canberra, Australia, 1954.

[10] Foster G., Campbell R., Adams W., Heritability, gain and C effects in rooting of western hemlock cuttings, Can. J. For. Res. 14 (1984) 628-638.

[11] Foster G.S., Genetic control of rooting ability of stem cuttings from loblolly pine, Can. J. For. Res. 20 (1990) 1361-1368.

[12] Frampton J., Hodges J.F., Nursery rooting of cuttings from seedlings of slash and loblolly pine, South. J. Appl. For. 13 (1989) $127-132$.

[13] Frampton L.J., Foster G.S., Field testing vegetative propagules, in: Ahuja M.R., Libby W.J. (Eds.), Clonal Forestry I - Genetics and Biotechnology, Springer-Verlag, Berlin, 1993, Vol. 1, pp. 110-114. 
[14] Gilmour A.R., Welham S.J., Thompson R., ASREML Reference Manual, NSW Agriculture Biometric Bulletin No. 3, 1999.

[15] Greaves A., Descriptions of seed sources and collections for provenances of Pinus caribaea, Tropical Forestry Papers No. 12, Commonwealth Forestry Institute, 1978, pp. 1-100.

[16] Greenwood M.S., Hutchison K.W., Maturation as a developmental process, in: Ahuja M.R., Libby W.J. (Eds.), Clonal Forestry I Genetics and Biotechnology, Springer-Verlag, Berlin, 1993, Vol. 1 , pp. 14-33.

[17] Haines J.R., Walker S.M., Mass vegetative propagation of slash $\times$ Caribbean pine: operational status and research directions, Proc. of the 22nd Southern Forest Tree Improvement Conference, Atlanta, Georgia, 1993, pp. 488

[18] Haines R.J., Clonal forestry - definition, record and rationale, Proc of the Queensland Forest Service Clonal Forestry Workshop, Gympie, Queensland, 1993, pp. 2.1-2.9.

[19] Haines R.J., Clonal forestry in Queensland and implications for hybrid breeding strategies, Hybrid Breeding and Genetics of Forest Trees, Proc. of QFRI/CRC-SPF Symposium, 9-14th April, Noosa, Queensland, Australia, 2000, pp. 386-389.

[20] Haines R.J., Copley T.R., Huth J.R., Nester M.R., Morphological features as a guide to the suitability of shoots of Pinus caribaea var. hondurensis $\times$ P. tecunumanii for use as cuttings, in: Gibson G.L. Griffin A.R., Matheson A.C. (Eds.), Breeding Tropical Trees: Population structure and genetic improvement strategies in clonal and seedling forestry, Proc. of the IUFRO conference, Pattaya, Thailand, November 1988, pp. 439-441.

[21] Haines R.J., Nikles D.G., Mass propagation of superior families and individual genotypes of some conifers in Queensland, Austr. For. 50 (1987) 106-111.

[22] Haines R.J., Walker S.M., Maturation questions relating to clona forestry, Proc. of the Queensland Forest Service Clonal Forestry Workshop, Gympie, Queensland, 1993, pp. 13.11-13.14.

[23] Haines R.J., Walker S.M., Copley T.R., The effect of decapitation and heavy pruning of ortets on the subsequent rooting of cuttings of Pinus caribaea var. hondurensis, in: Gibson G.L., Griffin A.R., Matheson A.C. (Eds.), Breeding Tropical Trees: Population structure and genetic improvement strategies in clonal and seedling forestry, Proc. of the IUFRO conference, Pattaya, Thailand, November 1988, pp. 437-438.

[24] Hamann A., Effects of hedging on maturation in loblolly pine: rooting capacity and root formation, MSc thesis, State University of New York, 1995.

[25] Heybroek H.M., Visser T., Juvenility in fruit growing and forestry, Acta Hortic. 56 (1976) 71-80.

[26] Kleinschmit J., Khurana D.K., Gerhold H.D., Libby W.J., Past, Present, and Anticipated applications of clonal forestry, in: Ahuja M.R., Libby W.J. (Eds.), Clonal Forestry II - Conservation and Application, Springer-Verlag, Berlin, 1993, Vol. 2, pp. 9-41.

[27] Lerner I.M., The genetic basis of selection, John Wiley and Sons Inc., New York, NY, 1958

[28] Lewty M.J., Effects of water logging on the growth and water relations of tree Pinus taxa, For. Ecol. Manage. 30 (1990) 189-201.

[29] Libby W.J., Ahuja J.R., Clonal forestry, in: Ahuja J.R., Libby W.J. (Eds.), Clonal Forestry II: Conservation and Application, SpringerVerlag, Berlin, 1993, Vol. 2, pp. 1-8.
[30] Libby W.J., Jund E., Variance associated with cloning, Heredity 17 (1962) 533-540.

[31] Mc Granahan M., Borralho N., Greaves B., Genetic control of propagation effects and the importance of stock plant age and source on early growth in cuttings of Pinus radiata, Silvae Genet. 48 (1999) 267-272.

[32] Mendenhall W., Wackerly D.D., Scheaffer R., Mathematical Statistics with Applications, Wadsworth Publishing Co, 1990.

[33] Nikles D.G., The first 50 years of the evolution of forest tree improvement in Queensland, Tree improvement for sustainable forestry: QFRI-IUFRO Conference, Caloundra, Queensland, 1996, pp. 51-64.

[34] Paterson A.H., Tanksley S.D., Sorrells M.E., DNA markers in plant improvement, Adv. Agron. 46 (1991) 39-90.

[35] Radosta P., Paques L.E., Verger M., Estimation of genetic and nongenetic parameters for rooting traits in hybrid larch., Silvae Genet. 43 (1994) 108-114.

[36] Reines M., Bamping J.H., Seasonal rooting response of slash and loblolly pine cuttings, J. For. 58 (1960) 646-647.

[37] Shepherd M., Huang S., Eggler P., Cross M., Dale G., Dieters M.J., Henry R., Directional selection in Pinus elliottii for adventitious rooting implicated by QTL correspondence in unrelated inbred and outbred hybrids with P. caribaea, submitted (2004).

[38] Shoemake L.J., Arnold M.A., Davies F.T., Provenance impacts transplant establishment and adventitious root regeneration of sycamore, J. Amer. Soc. Hortic. Sci. 129 (2004) 360-367.

[39] Simmonds N.W., Genetic Aspects: Populations and Selection, in, Principles of Crop Improvement, 1st ed., Longman Group, New York, 1981, pp. 66-121.

[40] Strauss S.H., Lande R., Namkoog G., Limitations of molecularaided selection in forest tree breeding, Can. J. For. Res. 22 (1992) $1050-1061$.

[41] Sutton B.C.S., Commercial delivery of genetic improvement to conifer plantations using somatic embryogenesis, International Conference on Wood, Breeding, Biotechnology and industrial expectations, Bordeaux, France, 2001, pp. 116.

[42] Tibbits W., White T.L., Hodge G., Joyce K.R., Genetic control of rooting ability of stem cuttings in Eucalyptus nitens, Austr. J. Bot. 45 (1997) 203-210.

[43] Walker S., Haines R., Dieters M., Beyond 2000: clonal forestry in Queensland, QFRI-IUFRO conference "Tree improvement for sustainable forestry", Caloundra, Queensland, Australia, 1996, pp. 351-354.

[44] Weir R.J., Goldfarb B., Loblolly and slash pine rooted cutting research at N.C. State University, Proc. of the 22nd Southern Forest Tree Improvement Conference, Atlanta, Georgia, 1993.

[45] Wilcox J.R., Farmer R.E.J., Heritability and C effects in early root growth of eastern cottonwood cuttings, Heredity 23 (1968) 239245 .

[46] Williams C.G., Savolainen O., Inbreeding depression in conifers, For. Sci. 41 (1996) 1-20.

[47] Ying C., Bagley W., Variation in rooting capability of Populus deltoides, Silvae Genet. 26 (1977) 204-207. 